Journal Review: The Development of Digital Economy in Indonesia

Journal Writer : Ahmad Zafrullah Tayibnapis, Lucia E.Wuryaningsih, Radita Gora

Review by : Fadel Muhammad Amin/130116086/C

\title{
The Development of Digital Economy in Indonesia Review
}

\section{by Fadel Muhammad Amin}

Kurikulum baru mengharuskan pak Ahmad meminta saya sebagai siswa untuk memberikan review atau ulasan mengenai paper yang beliau buat bersama timnya. Berarti ada suatu kegiatan dimana saya diperbolehkan untuk meliat pemikiran yang dituangkan dalam bentuk diksi dan kembali saya uraikan. Dalam pengertian akademis, review atau ulasan adalah aktivitas yang terdiri dari serangkaian kegiatan seperti, mengurai, membedakan, memilah sesuatu untuk dikelompokkan kembali menurut kriteria tertentu dan kemudian dicari kaitannya lalu ditafsirkan maknanya.

Ada suatu pernyataan pada abstraksi yang berbunyi the development of digital lifestyle and digital technology-based indsutries has become a necessity, but on the other hand, it will become "a serious threat" for traditional and conventional business as a result of change (Tayibnapis, Wuryaningsih, \& Gora, 2018, p. 14). Pemberian tanda kutip pada kalimat a serious threat yang apabila diartikan adalah ada suatu ancaman besar bagi bisnis yang berbasis tradisional dan konvensional menunjukkan penekanan hal yang sangat penting akan hal ini. Saya ingin mulai dengan pengertian terlebih dahulu dengan kata tradisional dan konvensional ini, tradisional adalah aksi dan tingkah laku yang keluar alamiah karena kebutuhan dari nenek moyang yang terdahulu, sedangkan konvensional adalah suatu bentuk sifat untuk hal-hal yang normal, biasa, dan mengikuti cara yang diterima secara umum, jika kita gabung dengan bisnis berarti tradisional berarti bisnis yang berasal dari nenek moyang kita dulu dan bisnis konvensional adalah bisnis yang lazim kita gunakan saat ini.

Ancaman bagi bisnis tradisional dan konvensional menurut saya sebagai hal yang "sangat lazim”, bagian dari resiko. Resiko yang diambil para pendahulu karena mereka yang membuat hal itu dan sebagian kita ikuti sampai sekarang. Walaupun kita adalah orang yang murah hati kita tidak 
akan bisa membendung kekuatan yang sangat besar, yang bisa kita lakukan saat ini adalah memberdayakan, beradaptasi, atau hal yang lebih besar dari itu kita membuat suatu peradaban baru dan ini sangat sulit dilakukan bahkan mustahil. Pada akhirnya, hal baru yang ada sekarang pun tentu akan menjadi kearifan lokal di masa yang akan datang.

Sharing economy is inevitable as the digital industry makes the acitivity more efficient (Tayibnapis, Wuryaningsih, \& Gora, 2018, p. 16). Tidak diragukan lagi bahwa fenoma sharing economy ini dimanfaatkan oleh berbagai kelompok atau individu dalam berbagai bidang bisnis yang ada. Sering dalam perjalanan saya menuju kampong halaman atau bepergian dari sana, sopir travel yang mengantar saling berbagi penumpang kepada temannya yang punya slot kursi kosong. Pengalaman yang saya alami ini menunjukkan bahwa hanya dengan teknologi berupa telpon dan sms, terjadi efesiensi yang sangat bermanfaat bagi para sopir itu, jadi semakin teknologi itu maju semakin besar pula efesiensi yang tercipta. Tetapi terkadang, efesiensi dapat pula membuat orang semakin malas, bodoh, dan kurang empati.

Jika ditanya sektor apa yang sangat penting diatas kepentingan yang lain dalam pengembangan platform digital saya akan menjawab pertanian dan pendidikan. Some start up business are now trying to get into the agricultural sector to help with capital difficulties that frequently haunt the live of farmers (Tayibnapis, Wuryaningsih, \& Gora, 2018, p. 17), memang yang saya teliti beberapa waktu lalu dari hasil wawancara saya kepada petani kesulitan modal menjadi masalah umum bagi mereka. Namun ini pula tidak lepas dari bagaimana peran pemerintah yang banyak melakukan pembangunan infrastruktur di wilayah pedesaan, banyaknya pembangunan berarti menyempitkan lahan pertanian. Pengetahuan dan alat teknologi terapan dalam bertani juga harusnya menjadi salah satu concern utama kita dalam melihat permasalahan ini.

Banyak kegiatan akademis saat ini membahas tentang bagaimana kita meningkat kualitas diri untuk bersaing dalam globalisasi di Indonesia secara khusus. Melihat hal ini memberikan kita gambaran besar bahwa terjadi peleburan antar masing-masing kebudayaan, yang jika cermati semakin hari semakin besar celahnya. Jika kita tidak waspada maka jelas bahwa ini akan menjadi ancaman serius bagi warga Negara Indonesia dalam memenuhi kebutuhan hidupnya. Disadari atau tidak kita telah menjadi bagian dari kejadian ini, be part of the modern lifestyle (Tayibnapis, Wuryaningsih, \& Gora, 2018, p. 14). 
Online business has a huge impact on people's mindset and behavior because the process is very fast and easy (Tayibnapis, Wuryaningsih, \& Gora, 2018, p. 17). Today's online usage has proven to be effective in spurring sales volume and market expansion which in turn it is capable of increasing non-oil exports and improving Indonesia's economic growth. Sudah jelas berarti bahwa internet ini memberikan tiga dampak besar dalam kehidupan manusia, yang mana tiga hal itu adalah efesiensi, accesability, dan jangkauan. Tiga hal itu nantinya akan sangat berdampak terhadap harga dan pertumbuhan ekonomi. 


\section{Tinjauan Pustaka}

Tayibnapis, A. Z., Wuryaningsih, L. E., \& Gora, R. (2018). The Development of Digital Economy in Indonesia. International Jornal of Management \& Business Studies, 8(3), 14. 